\title{
Induction of Cyclooxygenase-2 Accounts for Restraint Stress-Induced Oxidative Status in Rat Brain
}

\author{
José LM Madrigal', María A Moro', Ignacio Lizasoain', Pedro Lorenzo', A Patricia Fernández², José Rodrigo², \\ Lisardo Boscá ${ }^{3}$, and Juan C Leza ${ }^{*, 1}$ \\ 'Department of Pharmacology, Faculty of Medicine, University of Complutense, 28040 Madrid, Spain; ${ }^{2}$ Instituto Cajal CSIC, 28002 Madrid, \\ Spain; ${ }^{3}$ Instituto de Bioquímica UCM-CSIC, 28040 Madrid, Spain
}

\begin{abstract}
Cyclooxygenase (COX) is the rate-limiting enzyme in the metabolism of arachidonic acid into prostanoids. Although it is constitutively expressed in brain neurons, the inducible isoform (COX-2) is also upregulated in pathological conditions such as seizures, ischemia or some degenerative diseases. To assess whether COX-2 is regulated after stress, we have used adult male Wistar rats, some of which were immobilized during $6 \mathrm{~h}$. An increase in $\mathrm{PGE}_{2}$ concentration occurs in brain cortex after $2-6 \mathrm{~h}$ of the onset of stress as well as an enhancement of COX-2 protein. Immunohistochemical studies indicate that COX-2 is expressed in the cortex and hippocampus after stress in cells with morphology of neurons. Administration of PDTC $(150 \mathrm{mg} / \mathrm{kg})$, an inhibitor of the transcription factor NF- $\kappa$ B or MK$80 \mathrm{I}(0.2 \mathrm{mg} / \mathrm{kg})$, an $\mathrm{N}$-methyl-D-aspartate receptor blocker, prevents both stress-induced increase in COX-2 activity and protein levels, suggesting an implication of these factors in the mechanism by which stress induces COX-2 in brain. To assess if COX-2 accounts for the oxidative status seen in brain after stress, a group of animals were i.p. injected with NS-398, a specific COX-2 inhibitor I h prior to the onset of stress. NS-398 $(5 \mathrm{mg} / \mathrm{kg})$ decreases stress-induced malondialdehyde accumulation in cortex as well as prevents the stressinduced oxidation of glutathione. Finally, NS-398 reduced $\mathrm{Ca}^{2+}$-independent inducible nitric oxide synthase (iNOS, NOS-2) activity and lowered the stress-induced accumulation of NO metabolite levels in cortex. These effects of NS-398 seem to be due to the specific inhibition of COX-2, since it has no effect on stress-induced corticosterone release, glutamate release, and NF- $\kappa \mathrm{B}$ activation. These findings are discussed as possible damaging and/or adaptive roles for stress-induced COX-2 in the brain.

Neuropsychopharmacology (2003) 28, I579-1588, advance online publication, 23 April 2003; doi:10.1038/sj.npp.1300।87
\end{abstract}

Keywords: cyclooxygenase; neurodegeneration; oxidative status; stress

\section{INTRODUCTION}

The impact of stressor exposure on brain function has been widely investigated in the last years. Indeed, several reports indicate that long-lasting stress affects synaptic plasticity, dendritic morphology and neurogenesis in animals (Kim and Yoon, 1998), and induces both clinical and anatomical features of neurotoxic damage in humans (ie post-traumatic stress disorder) (Bremner et al, 1995). The main clinical correlates of stress-related neuropsychiatric disorders are depressive disorders, which are among the most common neuropsychiatric illnesses and represent a significant public health problem. Moreover, the relation between stressful events and the onset of disease (mainly cardiovascular and neurologic) is well documented (Baum and Posluszny, 1999).

\footnotetext{
*Correspondence: Dr JC Leza, Department of Pharmacology, Faculty of Medicine, University of Complutense, 28040 Madrid Spain, E-mail: jcleza@med.ucm.es

Received 03 January 2003; revised II February 2003; accepted 18 February 2003

Online publication: 26 February 2003 at http://www.acnp.org/citations/ Npp022603005/default.pdf
}

The precise molecular and cellular events induced by stress and responsible for the brain damage found in this condition are still a matter of debate. The high-output isoform of nitric oxide (NO) synthase (NOS-2) has been implicated in cellular toxicity in many cell systems, including the brain (for a review, see Gross and Wolin, 1995). In this context, we have demonstrated that chronic restraint stress induces the expression of NOS-2 in rat brain cortex and hippocampus and that its inhibition protects against stress-induced cell damage in this model (Olivenza et al, 2000). Once NOS-2 is expressed, the formation of large amounts of oxygen and nitrogen reactive species may account for the oxidation of cellular components found after chronic restraint stress in the rat brain (Liu et al, 1996; Madrigal et al, 2001b). A plausible consequence of this is the volume reduction that has been described in these two brain structures in chronically depressed patients and other stress-related disorders (Sheline et al, 1996; Koenen et al, 2001; Cotter et al, 2002).

In order to further investigate other possible sources of oxidative status in the brain, we decided to focus on the cyclooxygenase (COX) pathway. COX (also referred to as prostaglandin endoperoxide synthase) catalyzes the first steps of the synthesis of prostanoids by converting 
arachidonic acid into prostaglandin $\mathrm{H}_{2}$, which is the common substrate for specific prostaglandin synthases. The enzyme is bifunctional, with fatty acid COX and hydroperoxidase activities. COX exists as two distinct isoforms (Fu et al, 1990; Xie et al, 1991): whereas COX-1 is constitutively expressed as a housekeeping enzyme in nearly all tissues, mediating physiological responses, COX-2 is rapidly and transiently induced in cells that are involved in inflammation and is primarily responsible for the synthesis of prostanoids involved in pathological inflammatory processes. COX-2 is constitutively expressed in only a few tissues, for example, the brain, but is upregulated in a wide variety of cells by cytokines, mitogens, growth factors, and bacterial lipopolysaccharides. In the brain, COX-2 is induced in pathological conditions such as seizure, ischemia, or other neurodegenerative diseases (Yamagata et al, 1993; Nogawa et al, 1998), and has been involved in the damage associated in these conditions (reviewed in Pasinetti, 2001). According to its condition of inducible enzyme, and similarly to NOS-2, the promotor of the immediate-early gene COX-2 depends on the activation of several transcription factors including NF- $\kappa \mathrm{B}$ (Appleby et al, 1994).

By using a stress acute paradigm that has been reported to cause neuronal damage after chronic exposure (Magariños and McEwen, 1995), we investigated if COX-2 was involved in this process and whether some of the effects of acute stress on the brain can be regulated by this pathway, as well as the possible relation with the expression of NOS-2. In fact, the relation between these two sources of oxidative status has been described in many in vitro and in vivo systems after exposure to inflammatory mediators such as cytokines and endotoxin (LPS) (Salvemini et al, 1993, 1994). Thus, the purpose of the present study was to evaluate the role of COX-2 as one of the mechanisms through which stress may lead to cellular oxidative status in the brain and the elucidation of its mechanisms of induction, which may suggest possible neuroprotective pharmacological maneuvres after stress.

\section{MATERIALS AND METHODS}

\section{Animals}

Adult male Wistar rats weighing 225-250 g were used. All experimental protocols adhered to the guidelines of the Animal Welfare Committee of the Universidad Complutense following Spanish and European rules (DC 86/609/ CEE, RD 223/1988, and OM 13/X/1989). The rats were housed individually under standard conditions of temperature and humidity and a $12 \mathrm{~h}$ light/dark cycle (lights on at $08.00 \mathrm{am}$ ) with free access to food and water. All animals were maintained under constant conditions for 4 days prior to stress.

\section{Restraint Stress}

Rats were exposed to stress between 09:00 and 15:00 in the animal homeroom. The restraint was performed using a plastic rodent restrainer (Decapi-cone ${ }^{\mathbb{R}}$, Braintree, MA) that allowed for a close fit to rats during $6 \mathrm{~h}$ (Magariños et al, 1997; Leza et al, 1998) in their home cages. Control animals were not subjected to stress, but were handled at 9:00. Animals were killed immediately after restraint (still in the restrainer) using sodium pentobarbital. Blood for plasma determinations was collected by cardiac puncture and anticoagulated in the presence of trisodium citrate $(3.15 \%$ $\mathrm{w}: \mathrm{v}, 1 \mathrm{vol}$ citrate per $9 \mathrm{vol}$ blood). After decapitation, the brain was removed from the skull and both cortical areas and other structures were excised from the brain.

\section{COX Activity}

$\mathrm{PGE}_{2}$ and $\mathrm{PGD}_{2}$ are the predominant $\mathrm{PG}$ species in the brain, and $\mathrm{PGE}_{2}$ is most widely used as a marker of COX activity in neurons - specially in the cortex (Bishai and Coceani, 1992). Samples were purified using Amprep ${ }^{\mathrm{TM}}$ (RPN1900 Amersham, Buckinghamshire, UK) minicolums. After homogenizing cortices in the same buffer used for NOS activity determination (see below), the proper fraction needed for EIA isolation and $\mathrm{PGE}_{2}$ quantification were carried out following the manufacturer's instructions $\left(\mathrm{PGE}_{2}\right.$ EIA, Amersham).

\section{Characterization of COX-2, p65, and NOS-2 by Western Blot}

To determine the levels of COX-2 and NOS-2, tissues were homogenized in the same buffer used for NOS activity (see below); for p65, cytosolic and nuclear extracts were obtained (see below), and after centrifugation in a microcentrifuge for $15 \mathrm{~min}$, the proteins present in the supernatant were loaded $(20 \mu \mathrm{g})$ and size-separated in $10 \%$ SDS-polyacrylamide gel electrophoresis $(90 \mathrm{~mA})$. The gels were processed against the Ags and, after blotting onto a polyvinylidene difluoride membrane (Millipore, Bedford, MA, USA), were incubated with a specific goat polyclonal COX-2, rabbit polyclonal p65, and rat polyclonal NOS-2 antibodies (Santa Cruz Biotechnology, Santa Cruz, CA, USA; all three at 1:1000 dilution). Proteins recognized by the antibody were visualized on X-ray film by chemiluminiscence (ECL) following the manufacturer's instructions (Amersham lbérica, Madrid, Spain). Autoradiographs were quantified by densitometry (Software Total Lab. Dynamics Ltd Phoretix, Newcastle, UK), and several time expositions were analyzed to ensure the linearity of the band intensities.

\section{Immunohistochemistry}

Rats were anaesthetized with sodium pentobarbital and perfused through the left ventricle with $100 \mathrm{ml}$ of saline as a vascular rinse followed by $500 \mathrm{ml}$ of fixative solution containing $4 \%$ paraformaldehyde in $0.1 \mathrm{M}$ sodium phosphate buffer (PB), $\mathrm{pH}$ 7.4. The brains were removed, postfixed for $3 \mathrm{~h}$ in the same solution of paraformaldehyde at room temperature, and then cryoprotected by immersion overnight at $4^{\circ} \mathrm{C}$ in $0.1 \mathrm{M} \mathrm{PB}$ containing $30 \%$ sucrose.

Brains were frozen and serial $40-\mu \mathrm{m}$-thick frontal sections were cut with a Leitz sledge microtome. Free-floating sections of the whole brain were incubated with specific antiserum and processed by the avidin-biotin peroxidase complex (ABC) procedure (Guesdon et al, 1978; Hsu and Raine, 1981; Rodrigo et al, 1994) to visualize immunoreactive sites for COX-2. All the free-floating sections were 
incubated for $30 \mathrm{~min}$ in phosphate-buffered saline (PBS) containing 3\% normal goat serum (ICN Biochemicals, Barcelona, Spain) and $0.2 \%$ Triton X-100, and then in COX-2 diluted 1:2500 (Santa Cruz Biotechnology, Santa Cruz, CA, USA) in PBS/Triton X-100 overnight at $4^{\circ} \mathrm{C}$. After several washes in PBS, the sections were incubated with biotinylated goat anti-rabbit immunoglobulin for $1 \mathrm{~h}$. After washing, the sections were incubated with peroxidaselinked ABC (Vector Laboratories, Burlingame, CA, USA) for $90 \mathrm{~min}$. The peroxidase activity was demonstrated by the nickel-enhanced diaminobenzidine procedure (Rodrigo et al, 1994).

\section{Preparation of Cytosolic and Nuclear Extracts}

A modified procedure based on the method of Schreiber et al (1989) was used. Tissues (brain cortex) were homogenized with $300 \mu$ l of buffer A (10 mM HEPES, pH 7.9, $1 \mathrm{mM}$ EDTA, $1 \mathrm{mM}$ EGTA, $10 \mathrm{mM} \mathrm{KCl,} 1 \mathrm{mM}$ DTT, $0.5 \mathrm{mM}$ PMSF, $0.1 \mu \mathrm{g} / \mathrm{ml}$ aprotinin, $1 \mu \mathrm{g} / \mathrm{ml}$ leupeptin, $1 \mu \mathrm{g} /$ $\mathrm{ml}$ TLCK, $5 \mathrm{mM} \mathrm{NaF}, 1 \mathrm{mM} \mathrm{NaVO}, 0.5 \mathrm{M}$ sucrose, and $\left.10 \mathrm{mM} \mathrm{Na} \mathrm{MoO}_{4}\right)$. After $15 \mathrm{~min}$, Nonidet P-40 was added to reach a $0.5 \%$ concentration. The tubes were gently vortexed for $15 \mathrm{~s}$ and nuclei were collected by centrifugation at $8000 \mathrm{~g}$ for $5 \mathrm{~min}$. Supernatants were taken as a cytosolic fraction. The pellets were resuspended in $100 \mu \mathrm{l}$ of buffer A supplemented with $20 \%$ glycerol and $0.4 \mathrm{M} \mathrm{KCl}$, and gently shaken for $30 \mathrm{~min}$ at $4^{\circ} \mathrm{C}$. Nuclear protein extracts were obtained by centrifugation at $13000 \mathrm{~g}$ for $5 \mathrm{~min}$, and aliquots of the supernatant were stored at $-80^{\circ} \mathrm{C}$. All steps of the fractionation were carried out at $4{ }^{\circ} \mathrm{C}$.

\section{Electrophoretic Mobility Shift Assay (EMSA) for NF- $\kappa$ B}

Oligonucleotides were synthesized in an oligonucleotide synthesizer (Amersham Pharmacia Biotech, Little Chalfont, UK). The oligonucleotide sequence corresponding to the consensus NF- $\kappa \mathrm{B}$ binding site (nucleotides -978 to -952 ) of the murine NOS-2 promoter was $5^{\prime}$ TGCTAGGGGGA TTTTCCCTCTCTCTGT3 ${ }^{\prime}$ (Xie et al, 1994). Oligonucleotides were annealed with their complementary sequence by incubation for $5 \mathrm{~min}$ at $85^{\circ} \mathrm{C}$ in $10 \mathrm{mM}$ Tris- $\mathrm{HCl}, \mathrm{pH} \mathrm{8.0,}$ $50 \mathrm{mM} \mathrm{NaCl}, 10 \mathrm{mM} \mathrm{MgCl}_{2}$, and $1 \mathrm{mM}$ DTT. Aliquots of $50 \mathrm{ng}$ of these annealed oligonucleotides were end-labeled with Klenow enzyme (Amersham, Spain) fragment in the presence of $50 \mu \mathrm{Ci}$ of $\left[\alpha-{ }^{32} \mathrm{P}\right] \mathrm{dCTP}$ (Amersham, Spain) and the other unlabeled dNTPs in a final volume of $50 \mu \mathrm{l}$. DNA probe $\left(5 \times 10^{4} \mathrm{dpm}\right)$ was used for each binding assay of nuclear extracts as follows: $15 \mu \mathrm{g}$ of protein were incubated for $15 \mathrm{~min}$ at $4{ }^{\circ} \mathrm{C}$ with DNA and $2 \mu \mathrm{g}$ of poly(dl:dC), $5 \%$ glycerol, $1 \mathrm{mM}$ EDTA, $100 \mathrm{mM} \mathrm{KCl}, 5 \mathrm{mM} \mathrm{MgCl}_{2}, 1 \mathrm{mM}$ DTT, $10 \mathrm{mM}$ Tris- $\mathrm{HCl}, \mathrm{pH} \mathrm{7.8}$, in a final volume of $20 \mu \mathrm{l}$. The DNA-protein complexes were separated on native $6 \%$ polyacrylamide gels in $0.5 \%$ Tris borate-EDTA buffer (Díaz-Guerra et al, 1996). Supershift assays were carried out after incubation of the nuclear extracts with the antibodies against c-Rel proteins $(0.5 \mu \mathrm{g})$ for $1 \mathrm{~h}$ at $4{ }^{\circ} \mathrm{C}$, followed by EMSA (anti-p65 and anti-p-50 from Santa Cruz Biotechnology, Santa Cruz, CA). The amount of radioactivity was quantified in a Fuji BAS 1000 radioactivity detection system, and the gels were exposed to X-ray films to obtain high-resolution images. In experiments using
X-ray films (hyperfilm), different exposure times were employed to ensure that bands were not saturated.

\section{Lipid Peroxidation}

This was measured by the thiobarbituric acid test for malondialdehyde (MDA) following the method described by Das and Ratty (1987) with some modifications. Half forebrain was homogenized in $10 \mathrm{vol} 50 \mathrm{mM} \mathrm{PB}$ and deproteinized with $40 \%$ trichloroacetic acid (TCA) and $5 \mathrm{M} \mathrm{HCl}$, followed by the addition of $2 \%(\mathrm{w} / \mathrm{v})$ thiobarbituric acid in $0.5 \mathrm{M} \mathrm{NaOH}$. The reaction mixture was heated in a water bath at $90^{\circ} \mathrm{C}$ for $15 \mathrm{~min}$ and centrifuged at $12000 \mathrm{~g}$ for $10 \mathrm{~min}$. The pink chromogen was measured at $532 \mathrm{~nm}$ in a Beckman DU-7500 spectrophotometer. The results were expressed as nmol per mg of protein basis.

\section{Brain Glutathione}

These levels were measured as previously described (Anderson, 1985). The half forebrain was removed from the skull and frozen in ethanol. After that, tissues were rinsed in water and homogenized in $5 \% \mathrm{w} / \mathrm{v} 5$-sulfosalycilic acid and centrifuged at $4500 \mathrm{~g}$ for $5 \mathrm{~min}$. The supernatants were stored at $4{ }^{\circ} \mathrm{C}$ until assayed. This supernatant is oxidized by $6 \mathrm{mM} 5,5^{\prime}$-dithio-bis-(2-nitrobenzoic) acid (DTNB) to give reduced glutathione (GSSG) with the stoichiometric formation of 5-thio-2-nitrobenzoic acid (TNB). GSSG is reduced to glutathione (GSH) by the addition of highly specific glutathione reductase $(266 \mathrm{U} / \mathrm{ml}$ from stock enzyme with $143 \mathrm{mM}$ sodium phosphate and $6.3 \mathrm{mM} \mathrm{Na}_{4}$ EDTA at $\mathrm{pH} 7.5$ ) and $0.3 \mathrm{M} \mathrm{NADPH}$. The rate of TNB formation is measured at $412 \mathrm{~nm}$ in a Beckman DU7500 spectrophotometer and is proportional to the sum of GSH and GSSG present. Results were expressed as oxidized GSH per mg protein.

\section{NO Synthase Activity}

Cortices were snap-frozen in liquid nitrogen and stored until assayed at $-80^{\circ} \mathrm{C}$. Frozen tissues were homogenized by sonication (VibraCell) in an ice-cold buffer ( $\mathrm{pH} 7.4$ ) containing Tris- $\mathrm{HCl}(50 \mathrm{mM})$, sucrose $(320 \mathrm{mM})$, dithiothreitol $(1 \mathrm{mM})$, leupeptin $(10 \mu \mathrm{g} / \mathrm{ml})$ soybean trypsin inhibitor $(10 \mu \mathrm{g} / \mathrm{ml})$, and aprotinin $(2 \mu \mathrm{g} / \mathrm{ml})$, followed by centrifugation at $10000 \mathrm{~g}$ for $20 \mathrm{~min}$ at $4{ }^{\circ} \mathrm{C}$. NOS activity was determined in cell extracts under conditions (substrate and calcium concentration) of maximal activity to assess indirectly the amount of enzyme. The samples $(40 \mu \mathrm{l}$ of supernatant) were incubated at $37^{\circ} \mathrm{C}$ for $10 \mathrm{~min}$ in a buffer $\left(\mathrm{KH}_{2} \mathrm{PO}_{4}(50 \mathrm{mM}), \mathrm{MgCl}_{2}(1 \mathrm{mM}), \mathrm{CaCl}_{2}(0.2 \mathrm{mM})\right.$, L-valine $(50 \mathrm{mM})$, L-citrulline $(1 \mathrm{mM})$, L-arginine $(20 \mu \mathrm{M})$, and dithiothreitol $(1.5 \mathrm{mM}))$ containing $\mathrm{L}-\left[{ }^{14} \mathrm{C}\right]$ arginine $(0.1 \mathrm{mCi} / \mathrm{ml}$, Amersham Ibérica, Spain). The reaction was terminated by removing the substrate by the addition of $1 \mathrm{ml}$ of $1: 1 \mathrm{H}_{2} \mathrm{O}$ Dowex AF $500 \mathrm{~W}-8$ resin (Bio Rad). The activity of the calcium-dependent NOS was calculated from the difference between $\mathrm{L}-\left[{ }^{14} \mathrm{C}\right]$ citrulline produced from control samples and samples containing ethylene glycolbis(aminoethyl ether) $N, N, N^{\prime}$-tetraacetic acid (EGTA, $1 \mathrm{mM})$; the activity of the calcium-independent isoform was determined from the difference between samples with 
EGTA and samples containing $1 \mathrm{mM} \mathrm{N} \mathrm{N}^{\mathrm{G}}$-monomethyl-Larginine (L-NMMA). The $\left[{ }^{14} \mathrm{C}\right]$-bound radioactivity was counted using a liquid scintillation counter (Beckman LS6500) (Salter et al, 1991; Rees et al, 1995).

\section{Brain $\mathrm{NO}_{x}^{-}\left(\mathrm{NO}_{2}^{-}\right.$and $\left.\mathrm{NO}_{3}^{-}\right)$Levels}

NO production was estimated from the amounts of its stable metabolites nitrite $\left(\mathrm{NO}_{2}^{-}\right)$and nitrate $\left(\mathrm{NO}_{3}^{-}\right)$in brain tissue. It was calculated by first reducing $\mathrm{NO}_{3}^{-}$into $\mathrm{NO}_{2}^{-}$in the presence of $\mathrm{Cd}$ (Cortas and Wakid, 1990) and $\mathrm{NO}_{2}^{-}$was determined by a colorimetric assay based on the Griess reaction (Green et al, 1982) in a Thermomax ${ }^{\circledR}$ microplate reader (Molecular Devices). The measurement of $\mathrm{NO}_{x}^{-}$levels has been found to be a reliable technique to determine the synthesizing capacity of NOS in the brain (Salter et al, 1996).

\section{Plasma Corticosterone Levels}

Plasma was obtained within $1 \mathrm{~h}$ of obtaining blood samples by centrifuging the sample at $\approx 1000 \mathrm{~g}$ for $15 \mathrm{~min}$ immediately after stress. All plasma samples were stored at $-20^{\circ} \mathrm{C}$ before assay by using a commercially available kit by RIA of

${ }^{131}$ I-labeled rat corticosterone (DPC, Los Angeles, CA, USA). A gamma counter was used to measure radioactivity of the samples. The values obtained in control animals $(198.30 \pm 41.59 \mathrm{ng} / \mathrm{ml})$ match with the kit manufacturer's expected values in adult male Wistar rats at the time of blood extraction $(\approx 15: 00 \mathrm{~h})$.

\section{Plasma Glutamate Concentration}

Analysis of glutamate in plasma was performed by HPLC with fluorimetric detection (Perkin-Elmer Binary LC Pump 250 and Fluorescence Detector LC 240) (Lindroth and Mopper, 1979).

\section{Pharmacological Tools}

Various groups of animals were i.p. injected with a range $(0.5-10 \mathrm{mg} / \mathrm{kg})$ of NS-398 ( $\mathrm{N}$-[2-(cyclohexyloxy)-4-nitrophenyl] methanesulfonamide, a selective COX-2 inhibitor; Futaki et al, 1994) $1 \mathrm{~h}$ before restraint. NS-398 was dissolved in ethanol following the manufacturer's instructions. Selected groups of rats received PDTC (pyrrolidine dithiocarbamate, an inhibitor of the activation of NF- $\kappa \mathrm{B}$; Schreck et al, 1992) or MK-801 ([(+)-5-methyl-10,11dihydroxy-5H-dibenzo $(a, d)$ cyclohepten-5,10-imine]; dizocilpine), a specific noncompetitive $N$-methyl-D-aspartate (NMDA) antagonist (Wong et al, 1988). PDTC and MK-801 were administered at the onset of the stress and at doses used to reduce oxidative status in previous papers using this model (Madrigal et al, 2001a). Each experimental group contains six to eight animals.

\section{Protein Assay}

Protein assay Proteins were measured using bicinchoninic acid (Hill and Straka, 1988).

\section{Chemicals and Statistical Analyses}

Unless otherwise stated, the chemicals were from Sigma or RBI-Sigma (Spain). Data in text and figures are expressed as mean \pm SEM of the indicated number of experiments. Two group comparisons were evaluated by the paired or unpaired $t$-test, as appropriate. Multiple comparisons were analyzed by the ANOVA and Newman-Keuls test and $P<0.05$ was considered as statistically significant.

\section{RESULTS}

\section{COX-2 Activity and Expression in the Stressed Brain}

We studied the enzymatic activity of COX-2 by determining the levels of the main brain COX-2 reaction product $\mathrm{PGE}_{2}$ after restraint. Stress increased cortical $\mathrm{PGE}_{2}$ levels after 2, 4 , and $6 \mathrm{~h}(P<0.05 v s$ control, $27.8 \pm 2.6 \mathrm{ng} / \mathrm{g}$ protein, Figure 1a), and pretreatment with the selective COX-2 inhibitor NS-398 $(0.5-5 \mathrm{mg} / \mathrm{kg})$ attenuated significantly the stress-induced elevation of $\mathrm{PGE}_{2}$ after $6 \mathrm{~h}$ (Figure 1a). The $72 \mathrm{kDa}$ band corresponding to COX-2 protein increased at $4-6 \mathrm{~h}$ after the onset of stress as assessed by Western blot analysis (Figure $1 \mathrm{~b}$ ).

Concomitantly, we studied the localization of COX-2 in the brain. In control rats, few numbers of COX-2
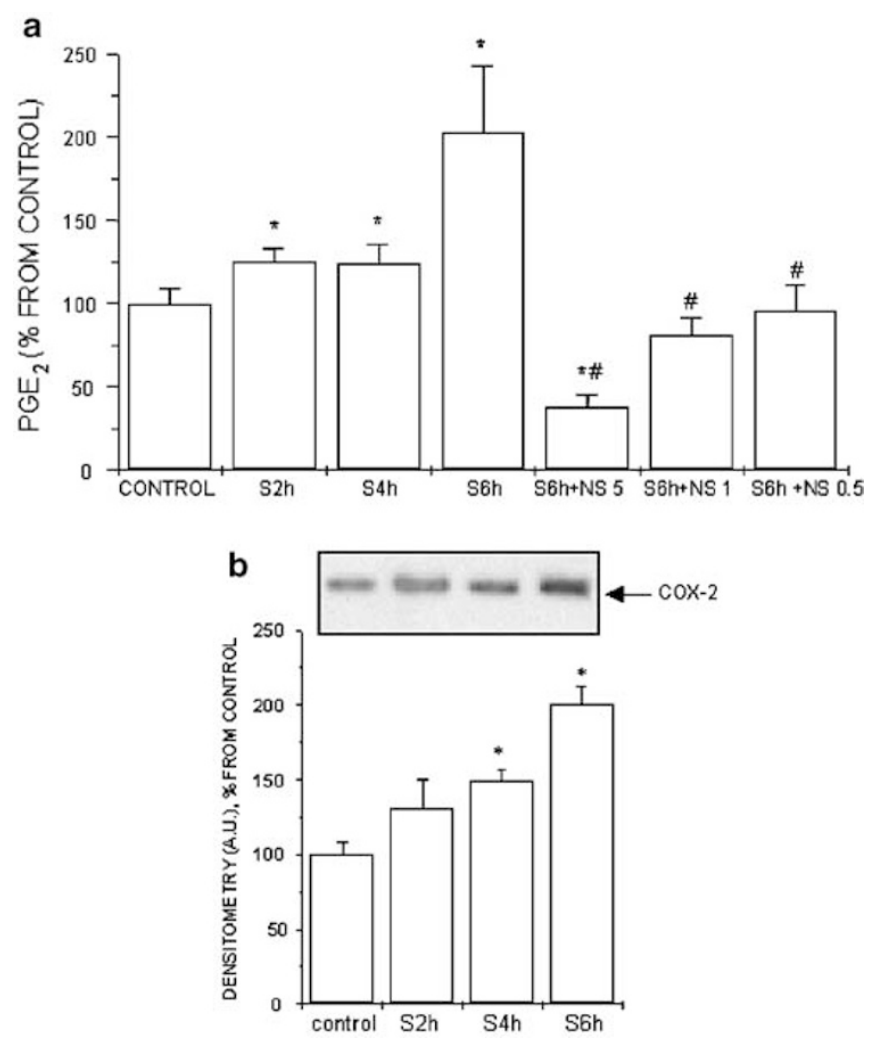

Figure I (a) Effect of restraint stress on $\mathrm{PGE}_{2}$ in the brain cortex after 2, 4 , and $6 \mathrm{~h}$ of stress (S2h, S4h, S6h). Effect of NS-398 (5, I, and $0.5 \mathrm{mg} / \mathrm{kg}$ ). $\mathrm{PGE}_{2}$ in control: $27.85 \pm 2.63 \mathrm{ng} / \mathrm{g}$ protein. The data represent the mean \pm SEM of six to eight rats. ${ }^{*} P<0.05$ vs control; ${ }^{\#} P<0.05$ vs $S 6 h$ (Newman-Keuls test). (b) Detection of COX-2 protein by Western blot (band: $72 \mathrm{kDa}$ ) and laser densitometric analysis of the band in the cortex of control and stressed rats by restraint during 2, 4, and $6 \mathrm{~h}$ (S2h, S4h, S6) The data are representative of three experiments. ${ }^{*} P<0.05$ vs control; ${ }^{\#} P<0.05$ vs S6h (Newman-Keuls test). 


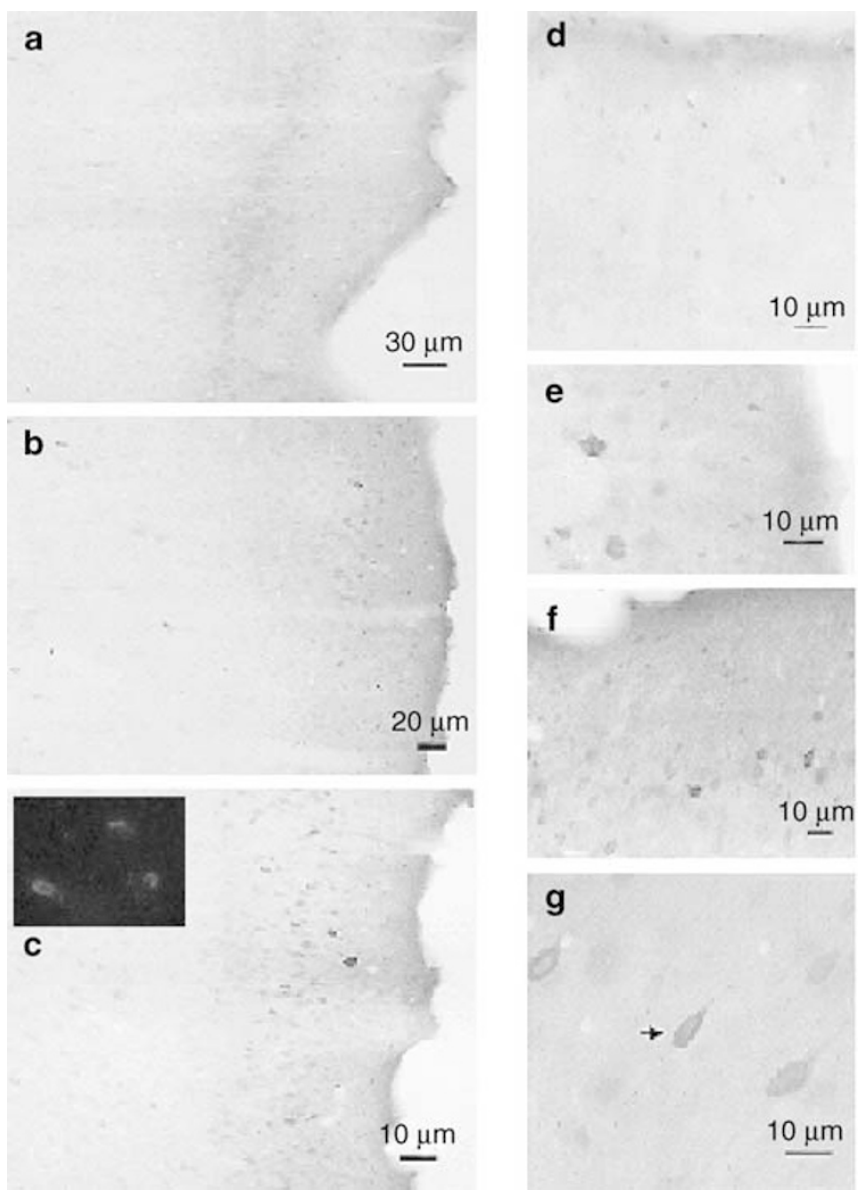

Figure 2 Comparative COX-2 staining and distribution of neuronal cells in sections from normal rat cingulate cortex (a and d) exposed to restrain

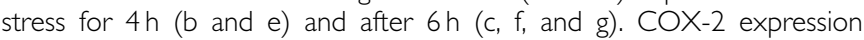
increases significatively in layers $\|-\| I$ and $\mathrm{V}-\mathrm{VI}$ of the cingulate cortex (after $4 \mathrm{~h}$ of stress (b) and after $6 \mathrm{~h}$ of stress (c)). COX-2 expression was found in pyramidal neurons ( $g$, arrow) and neurons with fusiform or typical multipolar morphology as associative neurons. Inset: COX-2 positive neurons (Cy5-labeled) in the fronto-parietal cortex after $6 \mathrm{~h}$ of restraint stress. Scale bars: (a), (b), and (c), $20 \mu \mathrm{m}$; (d)-(g) and inset, $10 \mu \mathrm{m}$.

immunoreactive neurons were observed in selected brain cortical areas. The cingulate and frontal cortices show immunoreactive neurons in layers II-III and V-VI (Figure $2 \mathrm{a}, \mathrm{d})$. Occasional and scattered immunoreactive neurons were distributed through parietal, temporal, insular, and pyriform cortices. An increase in COX-2 immunoreactivity was observed after $4 \mathrm{~h}$ (Figure 2b,e) and $6 \mathrm{~h}$ (Figure 2c-g and inset) of the onset of stress. These neurons have normal morphological characteristics, with a large unstained round nucleus. The immunoreactivity was characteristically perinuclear as previously described (Yamagata et al, 1993). In control rats few COX-2 positive neurons were observed in some hippocampal, hypothalamic, and thalamic areas, increasing the number of immunoreactive neurons in these selected brain areas after 4 and $6 \mathrm{~h}$ (not shown).

\section{Mechanisms of COX-2 Expression in Stress}

To assess some possible mechanisms in COX-2 expression in stress, we studied the effects of the selective COX-2 inhibitor NS-398. NS-398 inhibited both stress-induced and

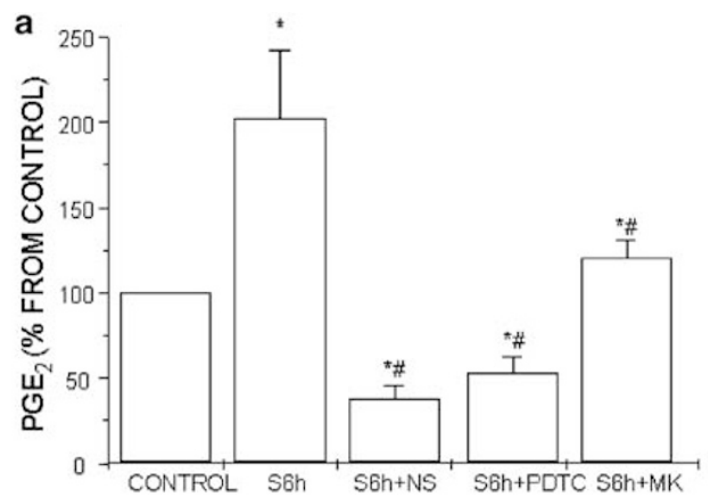

b

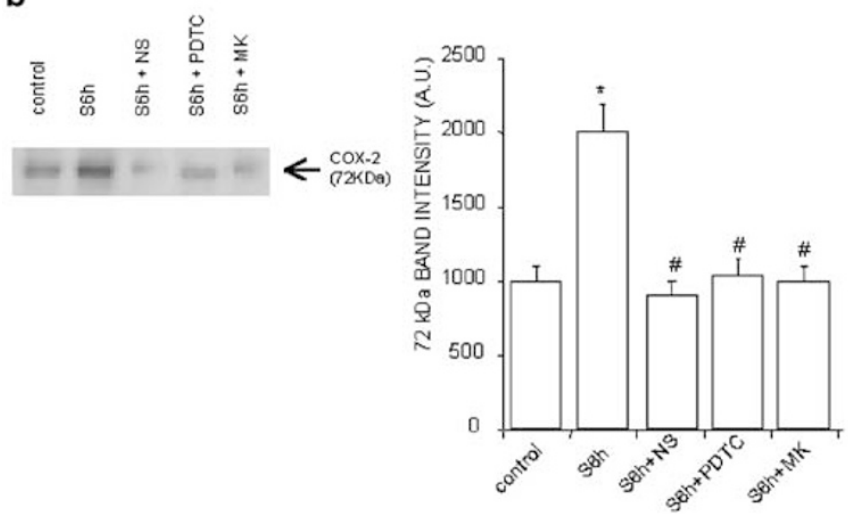

Figure 3 (a) Effect of restraint stress on $\mathrm{PGE}_{2}$ in the brain cortex after $6 \mathrm{~h}$ of stress (S6h) and stressed rats treated with NS-398 $5 \mathrm{mg} / \mathrm{kg}$ $(\mathrm{S} 6 \mathrm{~h}+\mathrm{NS}), \quad$ PDTC $150 \mathrm{mg} / \mathrm{kg}$ (S6+PDTC), and MK-80 I $0.2 \mathrm{mg} / \mathrm{kg}$ $(\mathrm{S} 6 \mathrm{~h}+\mathrm{MK}) . \mathrm{PGE}$ in control: $27.85 \pm 2.63 \mathrm{ng} / \mathrm{g}$ protein. The data represent the mean \pm SEM of six to eight rats. ${ }^{*} P<0.05$ vs control; ${ }^{\#} P<0.05$ vs S6h (Newman-Keuls test). (b) Detection of COX-2 protein by Western blot (band: $72 \mathrm{kDa}$, left panel) and laser densitometric analysis of the band (right panel) in the cortex of control and stressed rats by restraint during $6 \mathrm{~h}$ (S6h) and stressed rats treated with NS-398 $5 \mathrm{mg} / \mathrm{kg}(\mathrm{S} 6 \mathrm{~h}+\mathrm{NS})$, PDTC $150 \mathrm{mg} / \mathrm{kg}$ (S6 + PDTC), and MK-80 I $0.2 \mathrm{mg} / \mathrm{kg}$ (S6h + MK). *P $<0.05 \mathrm{vs}$ control; ${ }^{\#} P<0.05$ vs S6h (Newman-Keuls test). The data represent the mean \pm SEM of six rats.

control levels of $\mathrm{PGE}_{2}$ (Figure 3a), and also decreased the stress-induced COX-2 protein level after $6 \mathrm{~h}$ of stress (Figure 3b).

We then studied $\mathrm{PGE}_{2}$ concentration in PDTC-treated rats to assess the possible relation between COX-2 and the activation of NF- $\kappa$ B. Pretreatment with PDTC $(150 \mathrm{mg} / \mathrm{kg})$ reduced stress-induced increase in $\mathrm{PGE}_{2}$ concentration in $26.1 \pm 4.6 \%, P<0.05$ vs S6h (Figure $3 \mathrm{a}$ ). PDTC also reduced COX-2 expression at this time (Figure $3 \mathrm{~b}$ ).

Since it has been found that stimulation of glutamate receptors after excitatory amino acids (EAAs) released during stress leads to the activation of NF- $\kappa \mathrm{B}$ in neurons (Guerrini et al, 1995; Kaltschmidt et al, 1995), we decided to explore this possibility. The NMDA receptor blocker MK-801 (0.2 mg/kg) decreases both stress-induced $\mathrm{PGE}_{2}$ accumulation and COX-2 expression (Figure $3 a$ and $b$, respectively).

\section{Effect of Stress-Induced COX-2 Activation in Oxidative Parameters}

Restraint caused the accumulation of the mediator of lipid peroxidation MDA in cortex as soon as $6 \mathrm{~h}$ after stress 

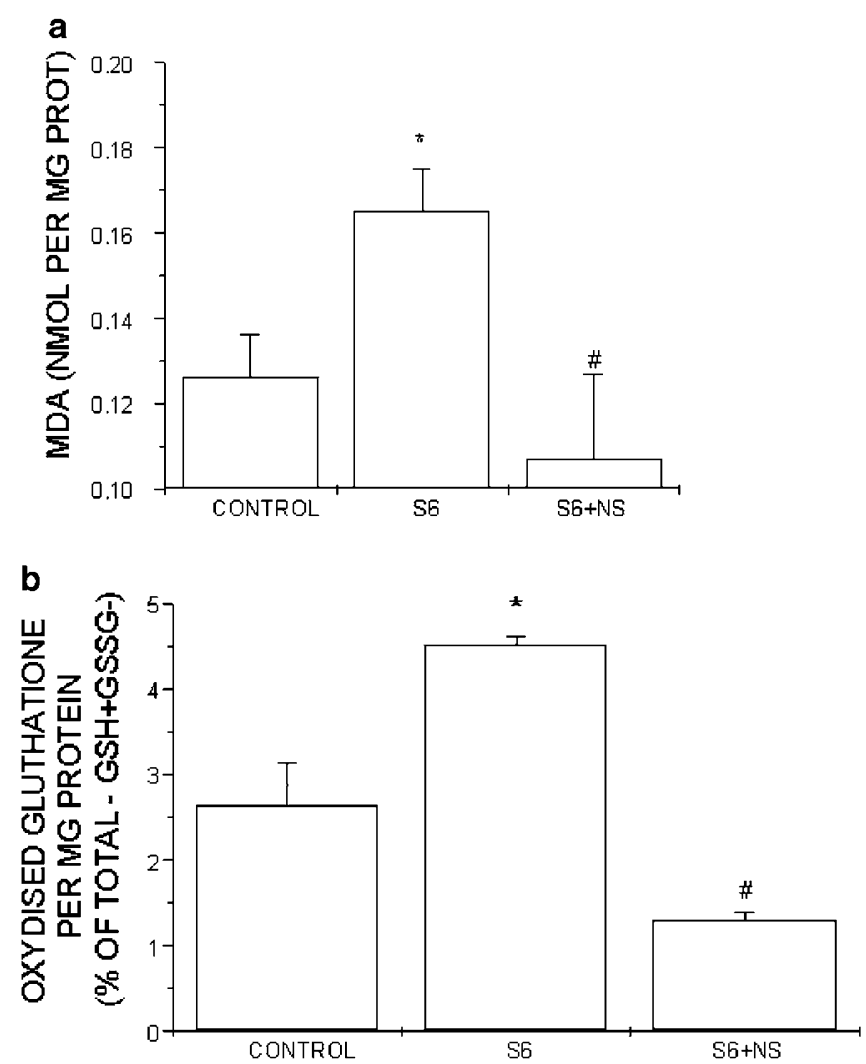

Figure 4 (a) Effect of acute restraint exposure on MDA levels in the brain cortex of control and stressed rats for $6 \mathrm{~h}$ (S6) with or without NS$3985 \mathrm{mg} / \mathrm{kg}$ (S6+NS) I h before restraint. The data represent the means \pm SEM of six rats. ${ }^{*} P<0.05$ vs control; ${ }^{\#} P<0.05$ vs $S 6$ (NewmanKeuls test). (b) Effect of acute restraint exposure on oxidised glutathione levels in the brain cortex of control and stressed rats for $6 \mathrm{~h}$ (S6) with or without NS-398 $5 \mathrm{mg} / \mathrm{kg}$ i.p. I h before restraint $(\mathrm{S} 6+\mathrm{NS})$. The data represent the means \pm SEM of eight rats. ${ }^{*} P<0.05$ vs. control; ${ }^{\#} P<0.05$ vs S6 (Newman-Keuls test).

exposure (Figure 4a). Concomitantly with the increase in lipid peroxidation markers, restraint produced an increase in the concentration of oxidised glutathione (Figure $4 \mathrm{~b}$ ). Administration of NS-398 (5 mg/kg i.p.) $1 \mathrm{~h}$ before the onset of stress prevented stress-induced increase in both parameters, MDA and oxidised glutathione (Figure $4 \mathrm{a}$ and b, respectively).

\section{Relation Between Stress-Induced COX-2 and NOS-2 in Brain}

The other powerful source of oxidative mediators, NOS-2, was expressed in the cortex after $6 \mathrm{~h}$ of stress exposure, as seen by Western blot analysis and activity studies (Figure 5a). This increase occurred concomitantly with an elevation in the stable metabolites of $\mathrm{NO}\left(\mathrm{NO}_{x}^{-}\right)$in brain tissue (Figure 5b). Pharmacological inhibition of COX-2 with NS-398 $(5 \mathrm{mg} / \mathrm{kg})$ prevented $\mathrm{Ca}^{2+}$-independent NOS activity (Figure $5 \mathrm{a}$ ) as well as $\mathrm{NO}_{x}^{-}$accumulation (Figure $5 \mathrm{~b}$ ), but had no effect on NOS-2 protein (Figure $5 \mathrm{a}$, inset).

To test the possibility that NS-398 acts via a direct mechanism on calcium-independent NOS activity, a citrulline assay was performed with cortical tissue from six rats injected with LPS (1 mg/kg i.p.) and killed after $24 \mathrm{~h}$. NS-398 $(10 \mu \mathrm{mol} / \mathrm{l})$ did not have any direct effect on this activity
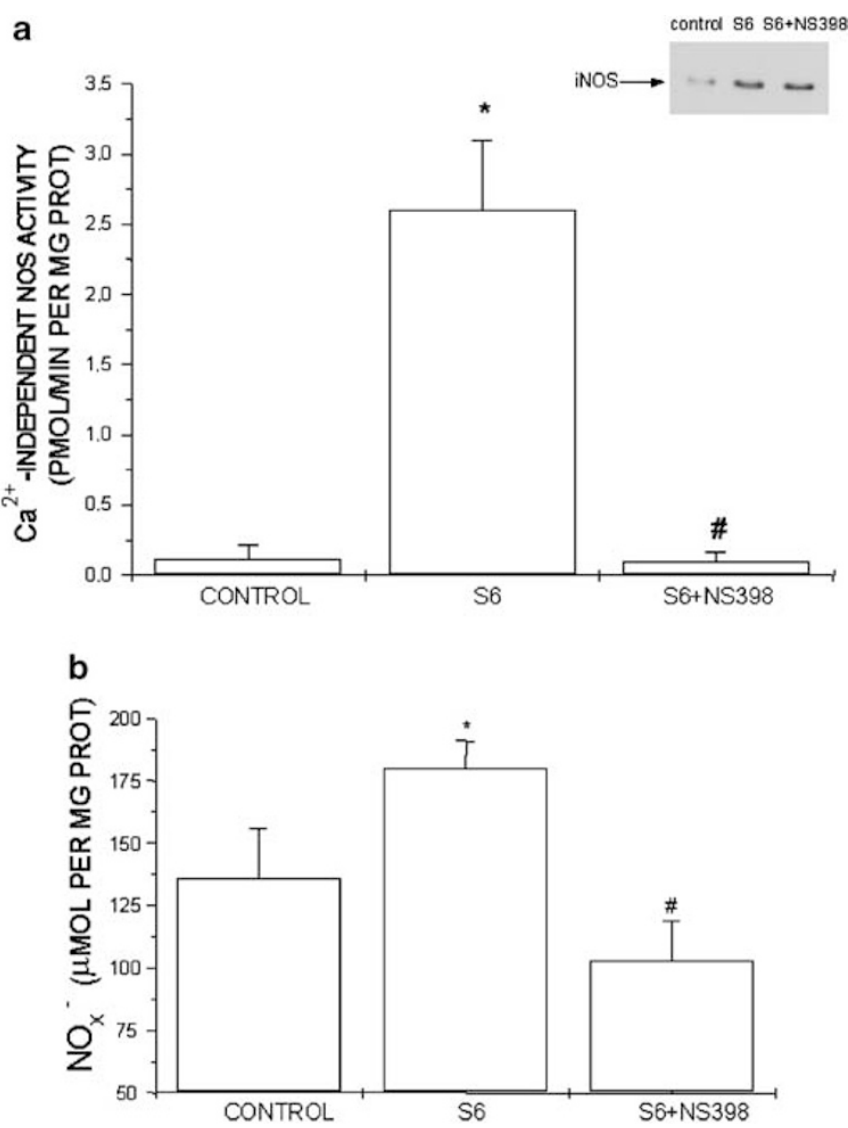

Figure 5 (a) Calcium-independent NOS activity in the cortex from control and stressed rats after $6 \mathrm{~h}$ of restraint (S6) and stressed rats receiving NS-398 5 mg/kg i.p. I h before restraint. Inset: detection of NOS2 protein by Western blot (band: $133 \mathrm{kDa}$ ) in control and stressed rats by restraint $6 \mathrm{~h}$ with or without NS-398. The data represent the mean \pm SEM of six to eight rats. ${ }^{*} P<0.05$ vs control; ${ }^{\#} P<0.05$ vs $S 6$ (Newman-Keuls test). (b) Effect of restraint exposure on $\mathrm{NO}_{2}^{-}$and $\mathrm{NO}_{3}^{-}\left(\mathrm{NO}_{x}^{-}\right)$levels in the brain cortex of control and stressed rats during $6 \mathrm{~h}$ (S6) with and without a dose of $5 \mathrm{mg} / \mathrm{kg}$ i.p. of NS-398 I h before stress. The data represent the means \pm SEM of six rats. ${ }^{*} P<0.05$ vs control; ${ }^{\#} P<0.05$ vs $S 6$ (Newman-Keuls test).

(LPS: $29.03 \pm 14.60 ;$ LPS + NS-398: $21.92 \pm 12.86 \mathrm{pmol} / \mathrm{min}$ per $\mathrm{mg}$ protein, $P>0.05)$. NS-398 $(10 \mathrm{mg} / \mathrm{kg})$ did not modify basal levels of $\mathrm{NO}_{x}^{-}$in brain tissue (control: $136 \pm 24$; NS398: $125 \pm 14 \mu \mathrm{mol}$ per mg protein, $P>0.05)$.

\section{Mechanisms of NS-398 Preventive Properties in Stress}

Once the preventive effect of NS-398 in stress-induced oxidative status was established, we sought to study possible effects prior to COX-2 inhibition.

First, to test the possibility that the effects of selective COX-2 inhibition were related to an interference on the general response to stress, we determined plasma corticosterone levels. NS-398 (5 mg/kg) did not affect corticosterone increase after $6 \mathrm{~h}$ of restraint (control: $198.30 \pm 40.59 \mathrm{ng} / \mathrm{ml}$; stress $6 \mathrm{~h}: 392.15 \pm 17.70 \mathrm{ng} / \mathrm{ml}, P<0.05$ vs control; stress $6 \mathrm{~h}$ plus NS-398: $428.55 \pm 41.92 \mathrm{ng} / \mathrm{ml}, n=6, P>0.05$ vs stress $6 \mathrm{~h}$ ).

Second, we determined the effect of NS-398 on stressinduced increase in plasma levels of glutamate. NS-398 $(5 \mathrm{mg} / \mathrm{kg})$ failed to act through inhibition of glutamate 
a

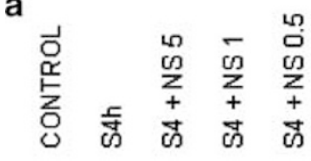

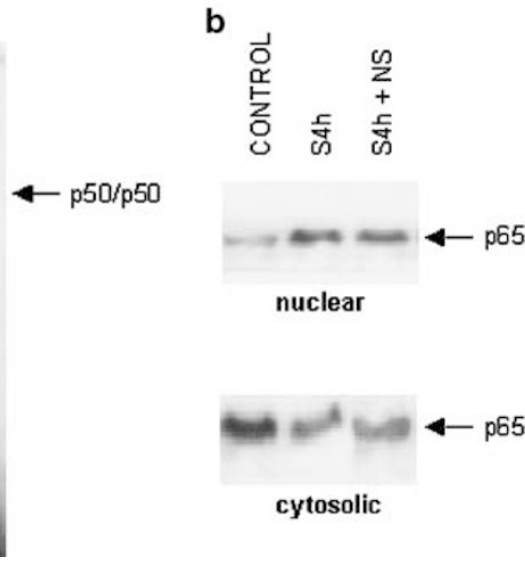

Figure 6 (a) NF- $\kappa \mathrm{B}$ translocation to the nucleus as measured by electrophoretic mobility shift assay (EMSA, left panel; see Materials and methods) of p50/p50 in nuclear extracts from the brain cortex of control and stressed rats during $4 \mathrm{~h}$ (S4h) with and without NS-398 (5, I, or $0.5 \mathrm{mg} / \mathrm{kg}$ i.p.) I h before stress. The data are representative of six rats. No statistical significances were found (Newman-Keuls test) in densitometric analysis. (b) Western blot analysis of p65 in nuclear and cytosolic extracts from the brain cortex of control and stressed rats during $4 \mathrm{~h}$ (S4h) with and without a dose of $5 \mathrm{mg} / \mathrm{kg}$ i.p. of NS-398 I h before stress. The data are representative of six rats. No statistical significances were found (NewmanKeuls test) in densitometric analysis.

release (control: $8266 \pm 483$; stress $6 \mathrm{~h}: 9469.8 \pm 416.9$; S6 + NS $5 \mathrm{mg} / \mathrm{kg}: 8962 \pm 172.5 \mathrm{ng}$ glutamate $/ \mathrm{ml}, \quad n=6$, $P>0.05$ vs control).

Third, to assess whether specific inhibition of COX-2 activity accounts for changes in NF- $\kappa$ B function, we studied the effects of NS-398 in the activation of NF- $\kappa$ B subunits. Interestingly, NS-398 did not modify either the stressinduced p50/p50 translocation to the nucleus as assessed by EMSA in nuclear extracts (Figure 6a) or the p65 activation as seen by the lack of changes in Western blot studies in cytosolic and nuclear fractions (Figure 6b).

\section{DISCUSSION}

The results of this study provide evidence that acute restraint stress induces the expression of COX-2 in rat brain. This conclusion is supported by Western blot, immunohistochemical, and enzymatic activity analyses. Furthermore, the finding of the effects of specific pharmacological inhibition of COX-2 preventing the increase on membrane lipid peroxidation mediators and the depletion of the main tissular antioxidant gluthatione strongly suggest that this COX isoform is involved in the accumulation of oxidative mediators found in the brain in this particular experimental model. Finally, an interaction of COX-2 with NOS-2, another known source of oxidative mediators in the stressed brain, is presented in this paper. The effects of NS398 seem to depend mainly on its COX-2 inhibitory properties, since it did not affect other mechanisms induced by stress such as corticosterone elevation, glutamate release, or NF- $\kappa$ B activation.
It is well known that COX-1 is constitutively expressed in nearly all tissues including brain, in neurons and astrocytes (Hewett et al, 2000). COX-2, although an inducible protein, is constitutively expressed in only a few tissues including the brain, particularly in neuronal soma, not in astrocytes, of different regions including cortex, amygdala, hippocampal formation, and the dorsal horn of the spinal cord (Yamagata et al, 1993; Breder et al, 1995). It becomes upregulated briefly-after 1-8 h-after seizure, trauma, intracerebral hemorrhage, ischemia, or other neurodegenerative diseases (Yamagata et al, 1993; Beiche et al, 1996; Nogawa et al, 1998; Knott et al, 2000; Kim et al, 2001; Gong et al, 2001). Other types of brain cells, including microglia, astrocytes, and vascular cells, do not express significant levels of COX-2 normally, but its expression is also increased after cerebral insults (Laflamme et al, 1999).

After the initial observation by Yamagata et al (1993) of the increase in COX-2 mRNA in mouse cerebral cortex after swim stress, the data presented here are, to our knowledge, the first to demonstrate the localization of COX-2 immunoreactive neurons in cingulate and frontal cortex, as well as the relation between COX-2 expression and the oxidative status seen in this condition. In our model, the cerebral cortex seems to be the area in which changes in COX-2 are more evident at this time of stress. Although most of the information about the changes seen after stress refers to the hippocampus, the cerebral cortex seems to be one of the target areas of damage in animal models of stress-related disorders and in humans with major depression (McEwen, 2000; Cotter et al, 2002; Bremner et al, 2002). This is also the brain area with the highest $\mathrm{PGE}_{2}$ content (the predominant PG species in the brain) (Abdel-Halim and Anggard, 1979).

The use of NS-398 as a tool to inhibit specifically COX-2 activity in the brain after peripheral administration has allowed us to conclude that the increase in activity and expression of this protein results in the production of an oxidative environment in the brain. The resulting membrane lipid peroxidation due to oxyradical attack on membrane fatty acids results in the formation of several cytotoxic aldehyde products such as MDA (Esterbauer et al, 1991). This process has been described to play an important role in the pathogenesis of several neurodegenerative diseases (reviewed in Mattson, 1998), and we and others have described the formation of large amounts of oxygen and nitrogen reactive species and subsequent lipid peroxidation during stress in the brain (Liu et al, 1996; Madrigal et al, 2001b), liver, and heart ( $\mathrm{Hu}$ et al, 2000). Concomitantly, an increase in lipid peroxidation may also be due to an insufficiency of the protective antioxidant systems (mainly GSH) as we previously demonstrated to occur in chronic (21 days) and acute (6h) restraint stress (Madrigal et al, 2001b; De Cristóbal et al, 2002). Thus, an important finding in the present study is the capacity of NS-398 to prevent the increase in brain oxidized GSH $(\sim 172 \%)$ that occurs after $6 \mathrm{~h}$ of stress exposure.

We have shown that NS-398 inhibits NOS-2 activity and decreases $\mathrm{NO}_{x}^{-}$accumulation without any direct effect on the enzyme, providing functional evidence that the interaction between these two sources of oxidative damage occurs at the level of their catalytic activity. The interactions between iNOS and COX-2 pathways may lead to contro- 
versial results depending on the cell system studied and the experimental conditions. In our model of restraint stress, we have shown that activation of COX-2 precedes NOS-2 probably because, although protein synthesis is required in both cases, COX-2 remains constitutively expressed in the brain (Yamagata et al, 1993). The relations between these two sources of oxidative status are consistent with the fact that, as observed also in brain ischemia, COX-2 is expressed before NOS-2 (6 and $12 \mathrm{~h}$, respectively, after transient occlusion of the MCA) (Nogawa et al, 1998) and $30 \mathrm{~min}$ to $2 \mathrm{~h}$ after reperfusion (Domoki et al, 1999). On the other hand, these data strongly suggest that both enzymes work in the same direction to produce oxidative status in acute stress. Further studies will be addressed to assess their relation in chronic stress but, in principle, one possibility is that the accumulation of oxidative-nitrosative species, including the powerful oxidant peroxynitrite $\left(\mathrm{ONOO}^{-}\right)$ seen after 21 days of repeated restraint (Madrigal et al, 2001b), came also from COX-2. Indeed, the two catalytic steps of COX-2, COX and peroxidase, are associated with the production of reactive oxygen species and, similarly to NOS-2, COX-2 could act as a source of superoxide for $\mathrm{ONOO}^{-}$formation (Vane et al, 1998).

It remains to study the precise mechanisms responsible for COX-2 expression and activity in stress. It is well known that basic gene induction mechanisms, including increase in NF$\kappa \mathrm{B}$-DNA binding, is fundamental in COX-2 expression in neurodegenerative disorders (Lukiw and Bazan, 1998). Furthermore, known inhibitors of NF- $\kappa$ B activation, including PDTC and PKC inhibitors, strongly reduced COX-2 transcription (Bauer et al, 1997; Callejas et al, 1999). The effect of PDTC decreasing stress-induced accumulation of $\mathrm{PGE}_{2}$ and $\mathrm{COX}-2$ protein described in this paper suggests the involvement of NF- $\kappa \mathrm{B}$ mechanisms. This might be an important mechanism since it has been demonstrated that $\mathrm{NF}-\kappa \mathrm{B}$ is activated in the brain after acute stress and accounts for NOS-2 expression in this model (Madrigal et al, 2001a) contributing to the oxidative status observed in this condition. On the other hand, it is possible also that locally produced lipid peroxidation products mediate COX-2 activity and expression. Indeed, COX-2 may be, in turn, upregulated by mediators of oxidative stress such as oxidized fatty acid metabolites (4-hydroxy-2-nonenal, HNE) and MDA, as has been shown in rat liver epithelial (RL34) cells (Kumagai et al, 2000). This possibility could explain the decrease in COX-2 expression induced by NS-398 observed in this paper. The possibility that, in chronic stresses, such a feedback process takes place deserves further attention.

It is well known that glutamate and other EAAs, mainly through the NMDA receptor, have been implicated in the pathogenesis of stress-induced brain injury (Sapolsky et al, 1990; Moghaddam, 1993; Magariños and McEwen, 1995; Kim et al, 1996). Several studies have described increases in brain (McBride et al, 1976; Gilad et al, 1990; Moghaddam, 1993) and plasma EAA levels (Milakofsky et al, 1985; De Cristóbal et al, 2002) following exposure to restraint or immobilization. Although glutamate concentration in this report has been determined in plasma, its increase after stress very likely reflects the profile of this EAA in the brain, as has been shown to be the case after cerebral ischemia (Baker et al, 1995; Castillo et al, 1997; De Cristóbal et al, 2001). It is well known that one of the main mechanisms of glutamate toxicity in neurodegenerative diseases is the oxidation of transporters which account for inhibition of EAA reuptake (Trotti et al, 1996). Although the present study focuses on changes that occurred after an acute unique stress session of $6 \mathrm{~h}$, the fact that specific blockade of NMDA receptors prevented both COX-2 activity and expression could indicate a new neuroprotective mechanism of strategies minimizing excitotoxicity, although caution should be emphasized with the use of pharmacological tools blocking physiological NOS-1 production of NO.

Finally, after the description of the role of COX-2 in stress and its relations with mediators of cellular oxidative status in the brain, the effects of NS-398 described in this paper seem to be directly related to the inhibition of COX-2 activity. First, NS-398 did not interfere with the systemic response to stress, since it did not affect the stress-induced corticosterone increase. Second, the fact that pharmacological inhibition of COX-2 by NS-398 did not modify the stress induced plasma glutamate levels discard a role in the glutamatergic mechanisms. Third, NS-398 did not affect the activity of NF- $\kappa$ B.

In conclusion, we have investigated the role of COX-2 after acute stress in the brain cortex. The increase in COX-2 expression and activity appears very early after the onset of stress, and accounts, at least in part, for the accumulation of oxidative mediators in this condition. A question of particular interest is the possibility that the changes seen would be a feature not of the deleterious effects of stress, but of some potentially reversible type of adaptive plasticity, as proposed by McEwen (1998). In this vein, the implication of constitutive COX-2 expression in the brain and its upregulation by stress could also be physiological (reviewed in Dubois et al, 1998), a question that deserves further consideration. In fact, a kind of 'oxidative stress' occurs in the normal brain (Reagan et al, 2000), and evidence for a physiological or pathophysiological role for lipid peroxidation has been presented (reviewed in Parola et al, 1999) in addition to its well-defined deleterious consequences (reviewed in Mattson, 1998).

\section{ACKNOWLEDGEMENTS}

The authors are indebted to Dr Bruce McEwen for his thoughtful suggestions. This work was supported by the Spanish Ministries of Science and Technology (BMC 20011912) and Health (ISCIII 01/0650) (JCL) and Fundación Santander Central Hispano Grants.

\section{REFERENCES}

Abdel-Halim MS, Anggard E (1979). Regional and species differences in endogenous prostaglandin biosynthesis by brain homogenates. Prostaglandins 17: 411-418.

Anderson M (1985). Determination of glutathione and glutathione disulfide in biological samples. Methods Enzymol 113: 548-555. Appleby SB, Ristimaki A, Neilson K, Narko K, Hla T (1994). Structure of the human cyclo-oxygenase-2 gene. Biochem J 302: 723-727.

Baker CJ, Fiore AJ, Frazzini VI, Choudhri TF, Zubay GP, Solomon RA (1995). Intraischemic hypothermia decreases the release of glutamate in the cores of permanent focal cerebral infarcts. Neurosurgery 36: 994-1001. 
Bauer MK, Lieb K, Schulze-Osthoff K, Berger M, Gebicke-Haerter PJ, Bauer $\mathrm{J}$ et al (1997). Expression and regulation of cyclooxygenase-2 in rat microglia. Eur J Biochem 243: 726-731.

Baum A, Posluszny DM (1999). Health psychology: mapping biobehavioral contributions to health and illness. Annu Rev Psychol 50: 137-163.

Beiche F, Scheuerer S, Brune K, Geisslinger G, Goppelt-Struebe M (1996). Up-regulation of cyclooxygenase-2 mRNA in the rat spinal cord following peripheral inflammation. FEBS Lett 390: $165-169$.

Bishai I, Coceani F (1992). Eicosanoid formation in the rat cerebral cortex. Contribution of neurons and glia. Mol Chem Neuropathol 17: 219-238.

Breder CD, Dewitt D, Kraig RP (1995). Characterization of inducible cyclooxygenase in rat brain. J Comp Neurol 355: 296-315.

Bremner JD, Randall P, Scott TM, Bronen RA, Seibyl JP, Southwick SM et al (1995). MRI-based measurement of hippocampal volume in patients with combat-related posttraumatic stress disorder. Am J Psychiatry 152: 973-981.

Bremner JD, Vythilingam M, Vermetten E, Nazeer A, Adil J, Khan $S$ et al (2002). Reduced volume of orbitofrontal cortex in major depression. Biol Psychiatry 51: 273-279.

Callejas NA, Casado M, Boscá L, Martin-Sanz P (1999). Requirement of nuclear factor kappaB for the constitutive expression of nitric oxide synthase- 2 and cyclooxygenase- 2 in rat trophoblasts. J Cell Sci 18: 3147-3155.

Castillo J, Dávalos A, Noya M (1997). Progression of ischaemic stroke and excitotoxic aminoacids. Lancet 349: 79-83.

Cortas NK, Wakid NW (1990). Determination of inorganic nitrate in serum and urine by a kinetic cadmium-reduction method. Clin Chem 36: 1440-1443.

Cotter D, Mackay D, Chana G, Beasley C, Landau S, Everall IP (2002). Reduced neuronal size and glial cell density in area 9 of the dorsolateral prefrontal cortex in subjects with major depressive disorder. Cereb Cortex 12: 386-394.

Das NP, Ratty AK (1987). Studies on the effects of the narcotic alkaloids, cocaine, morphine and codeine on nonenzymatic lipid peroxidation in rat brain mitochondria. Biochem Med Metab Biol 37: 256-264.

De Cristóbal J, Madrigal JLM, Lizasoain I, Lorenzo P, Leza JC, Moro MA (2002). Aspirin inhibits stress-induced increase in plasma glutamate, brain oxidative damage and ATP fall in rats. Neuroreport 13: 217-221.

De Cristóbal J, Moro MA, Dávalos A, Castillo J, Leza JC, Camarero J et al (2001). Neuroprotective effect of aspirin by inhibition of glutamate release after permanent focal cerebral ischaemia in rats. J Neurochem 79: 456-459.

Díaz-Guerra MJM, Velasco M, Martín-Sanz P, Boscá L (1996). Evidence for common mechanisms in the transcriptional control of type II nitric oxide synthase in isolated hepatocytes. Requirement of NF- $\kappa \mathrm{B}$ activation after stimulation with bacterial cell wall products and phorbol esters. J Biol Chem 271: 3011430120.

Domoki F, Veltkamp R, Thrikawala N, Robins G, Bari F, Louis TM et al (1999). Ischemia-reperfusion rapidly increases COX-2 expression in piglet cerebral arteries. Am J Physiol 277: H1207214.

Dubois RN, Abramson SB, Crofford L, Gupta RA, Simon LS, Van de Putte LBA et al (1998). Cyclooxygenase in biology and disease. FASEB J 12: 1063-1073.

Esterbauer H, Schaur RJ, Zollner H (1991). Chemistry and biochemistry of 4-hydroxynonenal, malonaldehyde and related aldehydes. Free Radical Biol Med 11: 81-128.

Fu JY, Masferrer JL, Seibert K, Raz A, Needleman P (1990). The induction and suppression of prostaglandin $\mathrm{H} 2$ synthase (cyclooxygenase) in human monocytes. $J$ Biol Chem 265: 16737-16740.
Futaki N, Takahasi S, Yokoyama M, Arai I, Higuchi S, Otomo S (1994). NS-398, a new anti-inflammatory agent, selectively inhibits prostaglandin $\mathrm{G} / \mathrm{H}$ synthase/cyclooxygenase (COX-2) activity in vitro. Prostaglandins 47: 55-59.

Gilad GM, Gilad VH, Wyatt RJ, Tizabi Y (1990). Region-selective stress-induced increase of glutamate uptake and release in rat forebrain. Brain Res 525: 335-338.

Gong C, Ennis SR, Hoff JT, Keep RF (2001). Inducible cyclooxygenase- 2 expression after experimental intracerebral hemorrhage. Brain Res 901: 38-46.

Green LC, Wagner DA, Glogowski J, Skipper PL, Whishnok JS, Tannenbaum SR (1982). Analysis of nitrate, nitrite and $\left[{ }^{15} \mathrm{~N}\right]$ in biological fluids. Anal Biochem 126: 131-138.

Gross SS, Wolin MS (1995). Nitric oxide: patophysiological mechanisms. Annu Rev Physiol 57: 737-769.

Guerrini L, Blasi F, Denis-Donini S (1995). Synaptic activation of $\mathrm{NF} \kappa \mathrm{B}$ by glutamate in cerebellar granule neurones in vitro. Proc Natl Acad Sci USA 92: 9077-9081.

Guesdon JL, Ternyck J, Avrameas S (1978). The use of avidinbiotin interaction in immunoenzymatic techniques. J Histochem Cytochem 27: 1131-1139.

Hewett SJ, Uliasz TF, Vidwans AS, Hewett JA (2000). Cyclooxygenase- 2 contributes to $N$-methyl-D-aspartate-mediated neuronal cell death in primary cortical cell culture. J Pharmacol Exp Ther 293: 417-425.

Hill HD, Straka JG (1988). Protein determination using bicinchoninic acid in the presence of sulfhydryl reagents. Anal Biochem 170: 203-208.

Hsu SM, Raine L (1981). Protein A, avidin and biotin in immunocytochemistry. J Histochem 79: 1349-1353.

$\mathrm{Hu}$ Y, Cardounel A, Gursoy E, Anderson P, Kalimi M (2000). Antistress effects of dehydroepiandrosterone. Protection of rats against repeated immobilisation stress-induced weight loss, glucocorticoid receptor production, and lipid peroxidation. Biochem Pharmacol 59: 753-762.

Kaltschmidt C, Kaltschmidt B, Bauerle PA (1995). Stimulation of ionotrophic glutamate receptors activates transcription factor $\mathrm{NF} \kappa \mathrm{B}$ in primary neurons. Proc Natl Acad Sci USA 92: 9618-9622.

Kim JJ, Foy MR, Thompson RF (1996). Behavioral stress modifies hippocampal plasticity through $N$-methyl-D-aspartate receptor activation. Proc Natl Acad Sci USA 93: 4750-4753.

Kim EJ, Lee JE, Kwon KJ, Lee SH, Moon CH, Baik EJ (2001). Differential roles of cyclooxygenase isoforms after kainic acid-induced prostaglandin $\mathrm{E}_{2}$ production and neurodegeneration in cortical and hippocampal cell cultures. Brain Res 908: $1-9$.

Kim JJ, Yoon KS (1998). Stress: metaplastic effects in the hippocampus. Trends Neurosci 21: 505-509.

Knott C, Stern G, Wilkin GP (2000). Inflammatory regulators in Parkinson's disease: NOS-2, lipocortin-1, and cyclooxygenases-1 and -2. Mol Cell Neurosci 6: 724-739.

Koenen KC, Driver KL, Oscar-Berman M, Wolfe J, Folsom S, Huang MT, Schlesinger L (2001). Measures of prefrontal system dysfunction in posttraumatic stress disorder. Brain Cogn 45: 6478.

Kumagai T, Kawamoto Y, Nakamura Y, Hatayama I, Satoh K, Osawa T (2000). 14-Hydroxy-2-nonenal, the end product of lipid peroxidation, is a specific inducer of cyclooxygenase-2 gene expression. Biochem Biophys Res Commun 273: 437-441.

Laflamme N, Lacroix S, Rivest S (1999). An essential role of interleukin-1beta in mediating NF-kappaB activity and COX-2 transcription in cells of the blood-brain barrier in response to a systemic and localized inflammation but not during endotoxemia. J Neurosci 19: 10923-10930.

Leza JC, Salas E, Sawicki G, Russell JC, Radomski MW (1998). The effect of stress on homeostasis in JCR:LA-cp rats: the role of nitric oxide. J Pharmacol Exp Ther 286: 1397-1403. 
Lindroth P, Mopper K (1979). High performance liquid chromatographic determination of subpicomole amounts of amino acids by precolumn fluorescence derivatization with o-phtaldialdehyde. Anal Chem 51: 1667-1674.

Liu J, Wang X, Shigenaga MK, Yeo HC, Mori A, Ames BS (1996). Immobilization stress causes oxidative damage to lipid, protein and DNA in the brain of rats. FASEB J 10: 1532-1538.

Lukiw WJ, Bazan NG (1998). Strong nuclear factor-kappaB-DNA binding parallels cyclooxygenase- 2 gene transcription in aging and in sporadic Alzheimer's disease superior temporal lobe neocortex. J Neurosci Res 53: 583-592.

Madrigal JLM, Moro MA, Lizasoain I, Lorenzo P, Castrillo A, Boscá $\mathrm{L}$ et al (2001a). Inducible nitric oxide synthase expression in brain cortex after acute restraint stress is regulated by nuclear factor $\kappa \mathrm{B}$-mediated mechanisms. J Neurochem 76: 532-538.

Madrigal JLM, Olivenza R, Moro MA, Lizasoain I, Lorenzo P, Rodrigo $\mathrm{P}$ et al (2001b). Glutathione depletion, lipid peroxidation and mitochondrial disfunction are induced by chronic stress in rat brain. Neuropsychopharmacology 24: 420-429.

Magariños AM, García Verdugo JM, McEwen BS (1997). Chronic stress alters synaptic terminal structure in hippocampus. Proc Natl Acad Sci USA 94: 14002-14008.

Magariños AM, McEwen BS (1995). Stress-induced atrophy of apical dendrites of hippocampal CA3c neurons: comparisons of stressors. Neuroscience 69: 83-88.

Mattson MP (1998). Modification of ion homeostasis by lipid peroxidation: roles in neuronal degeneration and adaptive plasticity. Trends Neurosci 21: 53-57.

McBride WJ, Hingtgen JN, Aprison MH (1976). Neurochemical correlates of behavior: levels of amino acids in four areas of the brain of the rat during drug-induced behavioral excitation. Pharmacol Biochem Behav 4: 53-57.

McEwen BS (1998). Protective and damaging effects of stress mediators. $N$ Engl J Med 338: 171-179.

McEwen BS (2000). Effects of adverse experiences for brain structure and function. Biol Psychiatry 48: 721-731.

Milakofsky L, Hare TA, Miller JM, Vogel WH (1985). Rat plasma levels of amino acids and related compounds during stress. Life Sci 36: 753-761.

Moghaddam B (1993). Stress preferentially increases extraneuronal levels of excitatory amino acids in the prefrontal cortex: comparison to hippocampus and basal ganglia. J Neurochem 60: 1650-1657.

Nogawa S, Forster C, Zhang F, Nagayama M, Ross ME, Iadecola C (1998). Interaction between inducible nitric oxide synthase and cyclooxygenase-2 after cerebral ischemia. Proc Natl Acad Sci USA 95: 10966-10971.

Olivenza R, Moro MA, Lizasoain I, Lorenzo P, Fernández AP, Rodrigo J et al (2000). Chronic stress induces the expression of inducible nitric oxide synthase in rat brain cortex. J Neurochem 74: 785-791.

Parola M, Bellomo G, Robino G, Barrera G, Dianzani MU (1999). 4Hydroxynonenal as a biological signal: molecular basis and pathophysiological implications. Antioxid Redox Signal 1: 255184.

Pasinetti GM (2001). Cyclooxygenase and Alzheimer's disease: implications for preventive initiatives to slow the progression of clinical dementia. Arch Gerontol Geriatr 33: 13-28.
Reagan LP, Magariños AM, Yee DK, Swzeda LI, VanBueren A, McCall AL, McEwen BS (2000). Oxidative stress and HNE conjugation of GLUT3 are increased in the hippocampus of diabetic rats subjected to stress. Brain Res 862: 292-300.

Rees DD, Cunha FQ, Assreuy J, Herman AG, Moncada S (1995). Sequential induction of nitric oxide synthase by Corynebacterium parvum in different organs of the mouse. $\mathrm{Br} J$ Pharmacol 114: 689-693.

Rodrigo J, Springall DR, Uttenthal O, Bentura ML, Abadía-Molina F, Riveros-Moreno V et al (1994). Localization nitric oxide synthase in the adult rat brain. Philos Trans $R$ Soc London B 345: 175-221.

Salter M, Duffy C, Garthwaite J, Strijbos PJ (1996). Ex vivo measurement of brain tissue nitrite and nitrate accurately reflects nitric oxide synthase activity in vivo. J Neurochem 66: $1683-1690$.

Salter M, Knowles RG, Moncada S (1991). Widespread tissue distribution, species distribution and changes in activity of $\mathrm{Ca}^{2+}$. dependent and $\mathrm{Ca}^{2+}$-independent nitric oxide synthases. FEBS Lett 291: 145-149.

Salvemini D, Misko TP, Masferrer JL, Seibert K, Currie MG, Needleman P (1993). Nitric oxide activates cyclooxygenase enzymes. Proc Natl Acad Sci USA 90: 7240-7244.

Salvemini D, Seibert K, Masferrer JL, Misko TP, Currie MG, Needleman P (1994). Endogenous nitric oxide enhances prostaglandin production in a model of renal inflammation. $J$ Clin Invest 93: 1940-1947.

Sapolsky R, Uno H, Robert C, Finch C (1990). Hippocampal damage associated with prolonged glucocorticoid exposure in primates. J Neurosci 10: 2897-2904.

Schreck R, Meier B, Männel DN, Dröge W, Baeuerle PA (1992). Dithiocarbamates as potent inhibitors of nuclear factor kappa B activation in intact cells. $J$ Exp Med 175: 1181-1194.

Schreiber E, Matthias P, Müller MM, Schaffner W (1989). Rapid detection of octamer binding proteins with 'mini-extracts', prepared from a small number of cells. Nucleic Acid Res 17: 6419.

Sheline YI, Wang PW, Gado MH, Csernansky JG (1996). Hippocampal atrophy in recurrent major depression. Proc Natl Acad Sci USA 93: 3908-3913.

Trotti D, Rossi D, Gjsedal O, Levy LN, Racagni G, Danbalt NC et al (1996). Peroxynitrite inhibits glutamate transporter subtypes. J Biol Chem. 271: 5976-5981.

Vane JR, Bakhle YS, Botting RM (1998). Cyclooxygenases 1 and 2. Annu Rev Pharmacol Toxicol 38: 97-120.

Wong EHF, Knight AR, Woodruff GN (1988). ${ }^{3}[\mathrm{H}] \mathrm{MK}-801$ labels a site on the $N$-methyl-D-aspartate receptor channel complex in rat brain membranes. J Neurochem 50: 274-281.

Xie WL, Chipman JG, Robertson DL, Erikson RL, Simmons DL (1991). Expression of a mitogen-responsive gene encoding prostaglandin synthase is regulated by mRNA splicing. Proc Natl Acad Sci USA 88: 2692-2696.

Xie Q-W, Kashiwabara Y, Nathan C (1994). Role of transcription factor NF- $\kappa \mathrm{B} / \mathrm{Rel}$ in induction of nitric oxide synthase. J Biol Chem 269: 4705-4708.

Yamagata K, Andreasson KI, Kaufmann WE, Barnes CA, Worley PF (1993). Expression of a mitogen-inducible cyclooxygenase in brain neurones: regulation by synaptic activity and glucocorticoids. Neuron 11: 371-386. 